Огляди літератури, оригінальні дослідження, погляд на проблему, випадок з практики, короткі повідомлення УДК 616.379-008.64:616.16-004.6]-092.9

DOI 10.11603/1811-2471.2020.v.i4.11769

\title{
МОДЕЛЬ МІКРОАНГІОПАТІЇ КІНЦІВОК ПРИ СТРЕПТОЗОЦИНОВОМУ ДІАБЕТІ
}

ㅇ. В. Чехлова

\section{Одеський національний медичний університет МОЗ України}

РЕЗЮМЕ. Залишається актуальною розробка моделей діабетичної мікроангіопатії кінцівок. Це ускладнення трапляється у всіх хворих з тяжким діабетом і, а за даними деяких дослідників, буває навіть при субкомпенсації у всіх пацієнтів з цукровим діабетом 2-го типу, і у 30 \% - з цукровим діабетом 1-го типу.

Мета дослідження - оцінка адекватності до потреб клініко-фізіологічних досліджень експериментальної моделі мікроангіопатії кінцівок при стрептозоциновому діабеті.

Матеріал і методи. Експериментальні дослідження були проведені за умов хронічного експерименту на 50 статевозрілих щурах лінії Вістар масою 180-250 г. Після введення стрептозоцину з експерименту виключали тварин із підвищеною резистентністю до панкреатотропної токсичної дії за критерієм відсутності гіперглікемії, після чого впродовж 6 тижнів виводили по 2 тварини для проведення морфологічних досліджень. На 7 тижні виводили з експерименту ще 10 тварин для оцінки ефективності експериментальної моделі. За станом решти 10 тварин спостерігали впродовж ще трьох тижнів.

Під час експерименту проводили лабораторний моніторинг глюкозурії, ацетонурії, протеїнурії, рівня глікемії. Формування ДМА підтверджували морфологічним дослідженням м'яких тканин задніх лапок щурів.

Статистичну обробку проводили непараметричними методами за допомогою програмного забезпечення Statistica 10.0 (Dell StatSoft Inc., США).

Результати. Середня маса тварин, залучених до дослідження, склала $(190,0 \pm 0,6)$ г при с $=2,9$ \%. У результаті аналізу розподілу значень вмісту глюкози крові у тварин після введення СЗТ, встановлено, що при амплітуді значень 9,9-17,0 ммоль/л в середньому цей показник склав $(14,2 \pm 0,2)$ ммоль/л. Подальший аналіз показав, що ефективність моделювання ЕЦД становила $92 \%$, що є прийнятним для підгострого експерименту.

Висновки. Розроблена патофізіологічна модель діабетичної мікроангіопатії $\epsilon$ адекватною до потреб клінічної фізіології. При діабетичній мікроангіопатії відзначається ремоделювання капілярного русла, що супроводжується зменшенням діаметра судин до $(7,7 \pm 0,7)$ мкм, а також явищами периваскулярної інфільтрації та порушення лімфодренажної функції. Обговорюється доцільність розробки ефективних методів непрямої реваскуляризації, спрямованих на відновлення перфузії та зменшення проявів діабетичної мікроангіопатії.

КЛючОВІ СлОВА: діабетична мікроангіопатія; лабораторна модель; стрептозоцин; клінічна фізіологія.

Вступ. Стрептозоцин розроблявся як антибіотик, проте досить швидко після його виділення з культури Streptomyces achromogenes були виявлені його діабетогенні властивості $[1,2]$. Сьогодні відомо, що цей препарат має високий ступінь спорідненості до бета-клітин острівців Лангерганса, тому його введення в організм ряду теплокровних тварин вибірково викликає руйнування панкреатичних клітинних структур [1-5]. У результаті виникають дефіцит інсуліну, гіперглікемія, полідипсія й поліурія, характерні для цукрового діабету (ЦД) 1-го типу [1]. Найчастіше стрептозоцинову модель цукрового діабету використовують у щурів, мишей і мавп, які найчутливіші до дії стрептозоцину. Рідше як експериментальних тварин використовують кролів, які менш чутливі до дії препарату $[2,4,5]$.

Критики дешевих експериментальних моделей із застосуванням панкреатотоксичних агентів вказують на ту обставину, що моделюється стан, ближчий до цукрового діабету 1-го типу, а в популяції переважають випадки інсулінонезалежного діабету 2-го типу [5]. Однак запропоновані ними альтернативні моделі з використанням генетично модифікованих тварин через їх високу вартість не отримали широкого застосування в експериментальній практиці $[1,2,4,5]$.

Питання розробки моделей діабетичної мікроангіопатії (ДМА) кінцівок залишається актуальним. Це ускладнення трапляється у всіх хворих із тяжким діабетом. За даними деяких дослідників, діабетична мікроангіопатія зустрічається навіть при субкомпенсації у всіх пацієнтів з ЦД 2-го типу й у $30 \%$ - з ЦД 1-го типу [6-9].

Патоморфоз МДА доволі складний. Мікроциркуляція порушується вже на ранніх стадіях ЦД, при цьому змінюється реологія циркулюючого пулу еритроцитів, які можуть бути гемолізованими, формувати сладж. Коректність терміна «хронічне дисеміноване внутрішньосудинне згортання крові» (відомого також як латентний синдром ДВС) $\epsilon$ дискутабельною [10, 11-13]. Однак з появою в мікроциркуляторному руслі еритротромбоцитарних агрегатів з випаданням ниток фібрину і підвищенням проникності капілярів різко падає перфузія тканин. Описані зміни супроводжуються дисфункцією ендотелію, тенденцією до гіперкоагуляції $з$ подальшим ремоделюванням судин, у результаті якого розвиваються дистрофічні та запальні зміни незворотного характеру $[10,11,14]$. 
Огляди літератури, оригінальні дослідження, погляд на проблему, випадок з практики, короткі повідомлення

Мета - оцінка адекватності до потреб клініко-фізіологічних досліджень експериментальної моделі мікроангіопатії кінцівок при стрептозоциновому діабеті.

Матеріал і методи дослідження. Експериментальні дослідження були проведені за умов хронічного експерименту на 50 статевозрілих щурах лінії Вістар масою 180-250 г.

Після введення стрептозоцину з експерименту виключали тварин із підвищеною резистентністю до панкреатотропної токсичної дії за критерієм відсутності гіперглікемії, після чого впродовж 6 тижнів виводили по 2 тварини для проведення морфологічних досліджень. На 7 тижні виводили з експерименту ще 10 тварин для оцінки ефективності експериментальної моделі. За станом решти 10 тварин спостерігали впродовж ще трьох тижнів.

Підготовку тварин, усі втручання, знеболювання та виведення з експерименту здійснювали у повній відповідності до вимог «Методичних рекомендацій» ДФЦ МОЗ України (Київ, 2001), а також правил GLP, що передбачено Європейською комісією з нагляду за проведенням лабораторних та інших досліджень, відповідно до Кодексу вченого України. Евтаназію тварин здійснювали з урахуванням положень, регламентованих додатком № 8 «Правила гуманного поводження з лабораторними тваринами», «Санітарних правил з обладнання, устаткування й утримування експериментальнобіологічних клінік (віваріїв)» № 1045-73 [15].

Лабораторних щурів утримували в індивідуальних боксах з 12-годинною зміною світла та темряви, вологістю повітря $60 \%$, постійною температурою $(22 \pm 1){ }^{\circ} \mathrm{C}$, з вільним доступом до води та їжі.

Експериментальний цукровий діабет (ЕЦД) відтворювали у щурів при внутрішньоочеревинному введенні стрептозоцину (СТ3) (60 мг/кг; «Alfa Aesar», США, [J61601, Lot: F30X011]), який розчиняли в натрієвому цитратному буфері $(\mathrm{pH}=4,5)$.

Масу тіла щурів визначали в грамах на спеціальних механічних лабораторних терезах ВЛ-120 (Томськ, Росія), погрішність методу складала $\pm 100 \mathrm{Mr}$.

Аналіз сечі проводили за допомогою діагностичних тест-смужок Citolab 3GK, Pharmasco (Україна). Визначали глюкозу та ацетон сечі у ммоль/л, білок сечі у г/л.

Для подальших експериментів обирали лише тих щурів, концентрація глюкози в крові яких перевищувала 12 ммоль/л. Ефективність моделювання ЕЦД становила 92-95 \% (в середньому лише у 1 щура із 20 концентрація глюкози в крові на 2 добу після введення СТЗ була меншою 10 ммоль/л).

Вміст глюкози у крові визначали за допомогою глюкозидазного методу [16].
Кількісне визначення глюкози в крові та сечі, а також ацетон і білок сечі в I тиждень після ін'єкції препарату визначали на 1, 3 і 7 доби, а потім 1 раз на тиждень до формування експериментальної діабетичної ангіопатії (ЕДА) (8 тиж.).

Формування ДМА підтверджували морфологічним дослідженням м'яких тканин задніх лапок щурів [11].

Статистичну обробку проводили непараметричними методами за допомогою програмного забезпечення Statistica 10.0 (Dell StatSoft Inc., США) [17].

Результати й обговорення. Середня маса тварин, залучених до дослідження, склала $(190,0 \pm 0,6)$ г при с $=2,9$ \%. У результаті аналізу розподілу значень вмісту глюкози крові у тварин після введення СЗТ встановлено, що при амплітуді значень 9,9-17,0 ммоль/л в середньому цей показник склав $(14,2 \pm 0,2)$ ммоль/л. Подальший аналіз показав, що ефективність моделювання ЕЦД становила 92 \%, що є прийнятним для підгострого експерименту [15].

Моніторинг глікемічного профілю впродовж 8 тижнів показав достатньо сталий вміст глюкози із тенденцією до підвищення. Це свідчить про високий ризик ушкодження ендотелію та ймовірність розвитку специфічних для ЦД ускладнень. 3 іншого боку, наведені значення свідчать про низький ризик виникнення гіперосмолярного синдрому в експериментальних тварин. На тлі ЕЦД тварини були мляві, апатичні, у них визначалися полідипсія та поліурія.

Проведений експрес-аналіз вмісту глюкози в сечі, а також ацетону і білка сечі, показав швидкий розвиток ознак діабетичної нефропатії. Вже наприкінці першого тижня екскреція білка в сечі перевищувала 25 мг на добу, складаючи в середньому 25,7士0,4 мг/добу, а до кінця 2 місяця спостереження цей показник збільшився до $(27,9 \pm 0,3)$ мг/добу. Вміст глюкози в усіх експериментальних тварин перевищував 2 \%, що відповідає середньому рівню $(11,1 \pm 0,3)$ ммоль/л.

Доволі високі рівні протеїнурії та глюкозурії свідчать про порушення функціонального резерву нирки, які $є$ наслідком дистрофії та часткового некрозу епітелію дистальних канальців, проліферації мезангіальних клітин та помірного потовщення базальної мембрани капілярів судинного клубочка.

У 56,3 \% випадків якісним методом визначалася ацетонурія, яка свідчить про наявність кетоацидозу. Втім, загальний стан тварин страждав мало, превалювали загальні поведінкові зміни, характерні для ЕЦД.

Отже, створена експериментальна модель адекватно відображає особливості ЦД середньо- 
Огляди літератури, оригінальні дослідження, погляд на проблему, випадок з практики, короткі повідомлення го ступеня тяжкості у стадії декомпенсації, що дозволяє вважати подальші висновки щодо перебігу ДА достатньо обґрунтованими.

Проведені гістологічні дослідження показали наявність суттєвих змін у всіх шарах шкіри уражених ДМА кінцівок. За умов відтворення ЕЦД вже через 6 тижнів у щурів розвивалася типова картина ДМА. Крім дистрофічних змін шкіри, у тварин спостерігали явища діабетичної периферійної полінейропатії, яка проявлялася слабкістю кінцівок та зменшенням рефлекторної відповіді на щипкове подразнення $[3,15]$. Спостерігали також ознаки температурної гіпералгезії.

Товщина периваскулярного інфільтрату склала, в середньому, $(7,9 \pm 0,8)$ мкм, при тому, що діаметр судин не перевищував $(7,7 \pm 0,7)$ мкм.

Загалом морфологічні зміни відповідали класичній роботі Є. В. Плєшанова (1990) [10]. В усіх проаналізованих зрізах визначалося нерівномірне потовщення базальної мембрани капілярів. Цей феномен супроводжувався вираженими дистрофічними змінами ендотеліоцитів і перицитів, підвищеною проникністю капілярів і накопиченням у базальному шарі тригліцеридів, глікопротеїдів, глікозаміногліканів і зруйнованих клітин, що, у свою чергу, асоціювалося із структурними змінами базальної мембрани у вигляді її потовщення, шаруватості і набряку. При ДМА відзначається ремоделювання капілярного русла у вигляді набряку інтерстицію і накопичення продуктів клітинного розпаду, тригліцеридів і глікопротеїдів. В інтерстиції збільшується кількість колагенових волокон і фібрилярних структур, між якими накопичуються й ущільнюються глікозаміноглікани, що сприяє розвитку і прогресуванню перикапілярного скле-

розу. Внаслідок динамічної резорбційної недостатності лімфатичних капілярів білкові продукти і тригліцериди з інтерстицію повністю не видаляються: навколо лімфатичних і кровоносних капілярів накопичується велика кількість білкового детриту і тригліцеридів [18]. Неповний дренаж продуктів клітинного розпаду внаслідок динамічної недостатності лімфатичних капілярів $є$ важливим фактором у патогенезі ДМА $[10,11]$.

Можна припустити, що при компенсованому ЦД розвиток ДМА може уповільнюватися, натомість при субкомпенсації або декомпенсованому діабеті описані процеси перебігають швидше, що може призводити до виражених функціональних та структурних змін у капілярах. Крім того, наведене свідчить про доцільність розробки ефективних методів непрямої реваскуляризації, спрямованих на відновлення перфузії та зменшення проявів ДМА.

Висновки. 1. Розроблена патофізіологічна модель діабетичної мікроангіопатії $€$ адекватною потребам клінічної фізіології.

2. При ДМА відзначається ремоделювання капілярного русла, що супроводжується зменшенням діаметра судин до $(7,7 \pm 0,7)$ мкм, а також явищами периваскулярної інфільтрації та порушення лімфодренажної функції.

3. Обговорюється доцільність розробки ефективних методів непрямої реваскуляризації, спрямованих на відновлення перфузії та зменшенням проявів ДМА.

Перспективи подальших досліджень. Плануємо розробку моделей реваскуляризації ішемізованих сегментів кінцівок у експериментальних тварин з ДМА.

\section{ЛІТЕРАТУРА}

1. Стрептозотоциновые модели сахарного диабета / В. К. Мазо, Ю. С. Сидорова, С. Н. Зорин, А. А. Кочеткова // Вопр. пит. - 2016. - Т. 85, № 4. - С. 14-21.

2. Furman B. L. Streptozotocin-induced diabetic models in mice and rats. Curr. Protoc. Pharmacol. - 2015. Vol. 70 (5). - P. 47.

3. Experimental diabetes mellitus in different animal models / A. Al-Awar, K. Kupai, M. Veszelka [et al.] // J. Diabetes Res. - 2016. - Vol. 2016. - 9051426.

4. King A. Animal models for diabetes: Understanding the pathogenesis and finding new treatments / A. King, J. Bowe // Biochem. Pharmacol. - 2016. - Vol. 99. - P. 1-10.

5. King A. J. The use of animal models in diabetes research / A. J. King // Br. J. Pharmacol. -2012. - Vol. 166 (3). P. 877-894.

6. Diabetic microvascular disease: An Endocrine Society Scientific Statement E. J. Barrett, Z. Liu, M. Khamaisi

[et al.] // J. Clin. Endocrinol. Metab. - 2017. - Vol. 102 (12). P. 4343-4410.

7. The effects of voluntary exercise and prazosin on capillary rarefaction and metabolism in streptozotocin-induced diabetic male rats / E. C. Dunford, E. Leclair, J. Aiken [et al.] // J. Appl. Physiol. (1985). - 2017. - Vol. 122 (3). P. 492-502.

8. Animal models of diabetic macrovascular complications: key players in the development of new therapeutic approaches / S. E. Heinonen, G. Genové, E. Bengtsson [et al.] // J. Diabetes Res. - 2015. - Vol. 2015. - 404085.

9. Indicators of lipid metabolism and their relation to disorders of microcirculation in diabetes mellitus / F. A. Zvershanovskiï, I. V. Zhulkevich, V. S. Danilishina, G. D. Zhulkevich // Probl. Endokrinol. - 1987. - Vol. 33 (4). - P. 15-18.

10. Плешанов Е. В. Патоморфогенез диабетических микроангиопатий, их патогенетическая профилактика и 
Огляди літератури, оригінальні дослідження, поглядн терапия: дисс. на соискание научн. степени д-ра мед. наук 14.00.03 - эндокринология, 14.00 .15 - патологическая анатомия / Е. В. Плешанов. - К., 1990. - 366 с.

11. Nerlich A. Morphologie von Basalmembran- und assoziierten Matrixproteinen in normalem und pathologischem Gewebe / A. Nerlich // Veroff Pathol. - 1995. Vol. 145. - P. 1-139.

12. Amlodipine ameliorates ischemia-induced neovascularization in diabetic rats through endothelial progenitor cell mobilization / J. Sun, J. Xie, L. Kang [et al.] // Biomed. Res. Int. - 2016. - Vol. 2016. - 3182764.

13. Food fibers as modifiers of homeostasis in patients with diabetes mellitus / S. G. Vaĭnsteĭn, I. V. Zhulkevich, M. S. Dubkin, N. K. Cherno //Ter. Arkh. -1987. - Vol. 59 (11).P. 29-31.

14. Швед М. І. Патогенетичні аспекти формування діабетичних ангіопатій / М. І. Швед, А. П. Дуднік, І. В. Жулкевич // Вісник наук. досліджень. - 1998. - № 1-2. С. 56-58.

15. Антологія біоетики / За ред. Ю. І. Кундієва. Львів : Бак, 2003. - 592 с.

16. Кишкун, А. А. Клиническая лабораторная диагностика / А. А. Кишкун. - М. : ГЭОТАР-Медиа, 2008. 720 c.

17. Боровиков В. П. Statistica - Статистический анализ и обработка данных в среде Windows / В. П. Боровиков, И. П. Боровиков - М. : Информац.-издат. дом «Филинъ». $-1998 .-608$ с.

18. Экспериментальное и клиническое обоснование применения пищевых волокон в лечении сахарного диабета : тезисы Всесоюзной конф. «Химия пищевых добавок», 25-27 апреля 1989 г., Черновцы / И. В. Жулкевич, С. Г. Вайнштейн. - Чернівці, 1989. - С. 182.

\section{REFERENCES}

1. Mazo, V.K., Sidorova, Yu.S., Zorin, S.N., \& Kochetkova, A.A. (2016). Streptozototsinovyye modeli sakharnogo diabeta [Streptozotocin models of diabetes mellitus]. Vopr. Pitan. - Nutrition Issues, 85 (4), 14-21 [in Russian].

2. Furman, B.L. (2015). Streptozotocin-induced diabetic models in mice and rats. Curr. Protoc. Pharmacol., 70 (5), 47.

3. Al-Awar, A., Kupai, K., Veszelka, M., Szűcs, G., Attieh, Z., Murlasits, Z., ..., \& Varga, C. (2016). Experimental diabetes mellitus in different animal models. J. Diabetes Res., 2016, 9051426.

4. King, A., \& Bowe, J. (2016). Animal models for diabetes: Understanding the pathogenesis and finding new treatments. Biochem. Pharmacol., 99, 1-10.

5. King, A.J. (2012). The use of animal models in diabetes research. Br. J. Pharmacol., 166 (3), 877-894.

6. Barrett, E.J., Liu, Z., Khamaisi, M., King, G.L., Klein, R., Klein, B.E.K., ..., \& Casellini, C.M. (2017). Diabetic microvascular disease: An Endocrine Society Scientific Statement. J. Clin. Endocrinol. Metab., 102 (12), 4343-4410.

7. Dunford, E.C., Leclair, E., Aiken, J., Mandel, E.R., Haas, T.L., Birot, O., \& Riddell, M.C. (2017). The effects of voluntary exercise and prazosin on capillary rarefaction and metabolism in streptozotocin-induced diabetic male rats. J. Appl. Physiol. (1985), 122 (3), 492-502.

8. Heinonen, S.E., Genové, G., Bengtsson, E., Hübschle, T., Åkesson, L., Hiss, K., ..., \& Gomez, M.F. (2015). Animal models of diabetic macrovascular complications: key players in the development of new therapeutic approaches. J. Diabetes Res., 2015, 404085.

9. Zvershanovskiĭ, F.A., Zhulkevich, I.V., Danilishina, V.S., \& Zhulkevich, G.D. (1987). Indicators of lipid metabolism and their relation to disorders of microcirculation in diabetes mellitus. Probl. Endokrinol., 33 (4), 15-18.

10. Pleshanov, Ye.V. (1990). Patomorfogenez diabeticheskikh mikroangiopatiy, ikh patogeneticheskaya pro- filaktika i terapiya [Pathomorphogenesis of diabetic microangiopathies, their pathogenetic prevention and therapy]. Doctor's thesis. Kyiv [in Russian].

11. Nerlich, A. (1995). Morphologie von Basalmembran- und assoziierten Matrixproteinen in normalem und pathologischem Gewebe. Veroff Pathol., 145, 1-139.

12. Sun, J., Xie, J., Kang, L., Ferro, A., Dong, L., \& Xu, B. (2016). Amlodipine ameliorates ischemia-induced neovascularization in diabetic rats through endothelial progenitor cell mobilization. Biomed. Res. Int., 2016, 3182764.

13. Vaĭnsteĭn, S.G., Zhulkevich, I.V., Dubkin, M.S., \& Cherno, N.K. (1987). Food fibers as modifiers of homeostasis in patients with diabetes mellitus. Ter. Arkh., 59 (11), 29-31.

14. Shved, M.I., Dudnik, A.P., \& Zhulkevych, I.V. (1998). Patohenetychni aspekty formuvannia diabetychnykh anhiopatii [Pathogenetic aspects of the formation of diabetic angiopathies]. Visnyk nauk. doslidzhen - Bull. Sci. Res., 1-2, 56-58 [in Ukrainian].

15. Kundiiev, Yu.I. (Ed.). (2003). Antolohiia bioetyky [Anthology of Bioetics]. Lviv: Bak [in Ukrainian].

16. Kishkun, A.A. (2008). Klinicheskaya laboratornaya diagnostika [Clinical laboratory diagnostics]. Moscow: GEOTAR-Media [in Russian].

17. Borovykov, V.P., \& Borovykov, Y.P. (1998). Statistica-Statystycheskyy analiz i obrabotka dannykh v srede Windows [Statistical analysis and data processing in the Windows environment]. Moscow: Informats.-izdat. dom «Fylyn» [in Russian].

18. Zhulkevich, I.V., \& Vaĭnsteĭn, S.G. (1989). Eksperimentalnoye i klinicheskoye obosnovaniye primeneniya pishchevykh volokon v lechenii sakharnogo diabeta [Experimental and clinical substantiation of the use of dietary fiber in the treatment of diabetes mellitus]. Proceedings from Vsesoyuzna konf. "Khimiya pishchevykh dobavok» - All-Union Conf. "Chemistry of food additives". Chernivtsi [in Russian]. 


\author{
Одесский национальный медицинский университет МОз Украины
}

РЕЗЮМЕ. Остается актуальной разработка моделей диабетической микроангиопатии конечностей. Данное осложнение наблюдается у всех больных с тяжелым диабетом, а по данным некоторых исследователей встречается даже при субкомпенсации у всех пациентов с сахарным диабетом 2-го типа, и у 30 \% - с сахарным диабетом 1-го типа.

цель - оценка адекватности потребностям клинико-физиологических исследований экспериментальной модели микроангиопатии конечностей при стрептозоциновом диабете.

Материал и методы. Экспериментальные исследования были проведены в условиях хронического эксперимента на 50 половозрелых крысах линии Вистар массой 180-250 г. После введения стрептозоцина из эксперимента исключали животных с повышенной резистентностью к панкреатотропному токсическому действию по критерию отсутствия гипергликемии, после чего в течение 6 недель выводили по 2 животных для проведения морфологических исследований. На 7 неделе выводили из эксперимента еще 10 животных для оценки эффективности экспериментальной модели. Остальных 10 животных наблюдали в течение еще трех недель.

Во время эксперимента проводили лабораторный мониторинг глюкозурии, ацетонурии, протеинурии, уровня гликемии. Формирование ГМА подтверждали морфологическим исследованием мягких тканей задних лапок крыс. Статистическую обработку проводили непараметрическими методами с помощью программного обеспечения Statistica 10.0 (Dell StatSoft Inc., США).

Результаты. Средняя масса животных, привлеченных к исследованию, составила $(190,0 \pm 0,6)$ г при сv=2,9 \%. При анализе распределения значений содержания глюкозы крови у животных после введения СЗТ установлено, что при амплитуде значений 9,9-17,0 ммоль/л в среднем этот показатель составил $(14,2 \pm 0,2)$ ммоль/л. Дальнейший анализ показал, что эффективность моделирования ЭЦД составляла 92 \%, что является приемлемым для подострого эксперимента.

Выводы. Показано, что разработанная патофизиологическая модель диабетической микроангиопатии является адекватной потребностям физиологии. При диабетической микроангиопатии отмечается ремоделирование капиллярного русла, сопровождающееся уменьшением диаметра сосудов до $(7,7 \pm 0,7)$ мкм, а также явлениями периваскулярной инфильтрации и нарушения лимфодренажной функции. Обсуждается целесообразность разработки эффективных методов непрямой реваскуляризации, направленных на восстановление перфузии и уменьшение проявлений диабетической микроангиопатии.

КЛючЕВЫЕ СЛОВА: диабетическая микроангиопатия; лабораторная модель; стрептозоцин; клиническая физиология.

\title{
MODEL OF EXTREMITY MICROANGIOPATHY IN STREPTOZOCIN DIABETES
}

\section{O. V. Chekhlova}

\section{Odesa National Medical University}

SUMMARY. The development of models of diabetic microangiopathy of the extremities remains relevant. This complication is observed in all patients with severe diabetes, and according to some researchers occurs even in subcompensation in all patients with type 2 diabetes, and in $30 \%$ - with type 1 diabetes.

The aim - to assess the adequacy to the needs of clinical and physiological studies of the experimental model of limb microangiopathy in streptozocin diabetes.

Material and Methods. Experimental studies were performed in a chronic experiment on 50 mature Wistar rats weighing 180-250 g. After administration of streptozocin from the experiment excluded animals with increased resistance to pancreatotropic toxicity in the absence of hyperglycemia, and then for 6 weeks for 2 weeks of withdrawal morphological studies. At $7^{\text {th }}$ week, ten other animals were removed from the experiment to evaluate the effectiveness of the experimental model. The condition of the remaining 10 animals was observed for another three weeks.

During the experiment, laboratory monitoring of glucosuria, acetonuria, proteinuria, glycemia was performed. The formation of DMA was confirmed by morphological examination of the soft tissues of the hind legs of rats.

Statistical processing was performed by nonparametric methods using Statistica 10.0 software (Dell StatSoft Inc., USA).

Results. The average weight of animals involved in the study was $(190.0 \pm 0.6) \mathrm{g}$ at $\mathrm{cv}=2.9 \%$. When analyzing the distribution of blood glucose values in animals after the introduction of streptozocin, it was found that the amplitude of the values of $9.9-17.0 \mathrm{mmol} / \mathrm{l}$ on average, this figure was $(14.2 \pm 0.2) \mathrm{mmol} / \mathrm{l}$. Further analysis showed that the efficiency of ECD modeling was $92 \%$, which is acceptable for subacute experiment.

Conclusions. It is shown that the developed pathophysiological model of diabetic microangiopathy is adequate to the needs of clinical physiology. In diabetic microangiopathy, remodeling of the capillary bed is observed, which is accompanied by a decrease in vascular diameter to $(7.7 \pm 0.7) \mu \mathrm{m}$, as well as the phenomena of perivascular infiltration and lymphatic drainage dysfunction. The expediency of developing effective methods of indirect revascularization aimed at restoring perfusion and reducing the manifestations of diabetic microangiopathy is discussed.

KEY WORDS: diabetic microangiopathy; laboratory model; streptozocin; clinical physiology. 